\title{
The Release of Potassium Ions from Candida albicans in the Presence of Polyene Antibiotics
}

\author{
By E. F. GALE \\ Sub-department of Chemical Microbiology, Department of Biochemistry, \\ University of Cambridge
}

(Received I6 July 1973; revised 23 August 1973)

\section{SUMMAR Y}

The addition of amphotericin methyl ester (AME) to suspensions of Candida albicans is followed by a progressively increasing rate of release of $\mathrm{K}^{+}$from within the cell. The time taken for a given rate of release to be reached depends upon the AME concentration (the product of AME concentration and time being approximately constant), the $\mathrm{pH}$ and concentration of buffer, the temperature, the suspension density, and the phase of growth of the organisms. The sensitivity of $C$. albicans to AME decreases during the growth of a batch culture, rapid decrease occurring after the organisms have reached the stationary phase of growth. The induction of $\mathrm{K}^{+}$release does not occur at $0^{\circ} \mathrm{C}$ and shows a high temperature coefficient over the range $\mathrm{I} 5$ to $30^{\circ} \mathrm{C}$.

Suspensions of mouse LS cells are 10 to 30 times less sensitive than Candida albicans towards AME, amphotericin B and nystatin; the two types of cell display little difference in sensitivity towards perimycin and candicidin, while mouse LS cells are more sensitive than $C$. albicans towards filipin.

Addition of sterols at the same time as AME increases the time taken for the release of $\mathrm{K}^{+}$to reach a given rate; of the sterols tested, zymosterol was the most effective in antagonizing AME, while ergosterol was approximately twice as effective as cholesterol on a molar basis. When organisms were exposed to AME for a short time, removed and resuspended in the absence of drug, the rate of $\mathrm{K}^{+}$ release continued to increase; this increase was prevented by ergosterol: $2 \times 10^{-5} \mathrm{M}$ ergosterol prevented further damage after organisms had been exposed to $10^{-6} \mathrm{M}$ AME.

\section{INTRODUCTION}

The polyene antibiotics are effective against eukaryotic cells in general but are without action on bacteria. Their action can be antagonized by sterols (Gottlieb, Carter, Wu \& Sloneker, I960), of which the most effective is ergosterol (Zygmunt \& Tavormina, I966). The polyenes appear to disorganize the structure of natural membranes containing sterols (Lampen, Arnow, Borowska \& Laskin, I962), as shown particularly by the insensitivity of certain mycoplasmas (Acholeplasma) grown in the absence of sterol and rendered sensitive by growth in the presence of sterol (Lampen, Gill, Arnow \& Magana-Plaza, I963; Weber $\&$ Kinsky, 1965). Polyenes differ in the size of the lactone ring, the number of double bonded $\mathrm{C}$ atoms and the degree of substitution. All the polyenes tested produce a change in the permeability of sensitive organisms, such as Candida spp., but the smaller molecules produce greater damage than large ones; thus filipin with $35 \mathrm{C}$ in the molecule induces leakage of $\mathrm{K}^{+}$, inorganic phosphate, amino acids and sorbose; nystatin with $46 \mathrm{C}$ releases $\mathrm{K}^{+}$and phosphate but not sorbose, while succinylperimycin with $63 \mathrm{C}$ releases $\mathrm{K}^{+}$only (Lampen, I966; Borowski \& Cybulska, 1967). Physical methods comparing the binding of polyenes to cholesterol have shown the binding affinity of polyenes to fall in the order: 
filipin > amphotericin B > nystatin > lagosin (Bittman \& Fischkoff, 1972; Norman, Demel, Kruyff, Guerts Van Kessel \& Van Deenen, 1972; Schaffner, 1973). The reaction between polyenes and sterols depends upon the latter having (i) $3 \beta$-hydroxy group on ring A, and (ii) 8 to Io carbon side chain on $\mathrm{C}-\mathrm{I} 7$, and is affected by the degree of planarity of the sterol nucleus (Zygmunt \& Tavormina, I966; Bittman \& Fischkoff, 1972). The permeability changes produced in natural membranes as a result of the interaction are attributed to micelle formation in the membrane followed by the formation of aqueous pores through the membrane (Finkelstein \& Cass, I968; Andreoli \& Monahan, I968; Cass, Finkelstein \& Krespi, 1970; Holts \& Finkelstein, 1970). Verkleij et al. (1973) have shown the appearance of aggregates 15 to $25 \mathrm{~nm}$ in diameter in acholeplasma membranes containing cholesterol and treated with filipin, and suggest that the mobilization of sterol and the formation of such aggregates would cause major disorganization of membranes whether pores were formed or not.

For the purposes of an investigation of the biochemistry of 'opportunistic' fungal infections and the use therein of polyene antibiotics, it was necessary to develop a rapid, quantitative method sufficiently accurate to assess the effects of differing growth conditions, alteration in sterol structure and composition, and modifications in polyene structure on the sensitivity of cells to polyenes. The instability of polyenes makes growth tests difficult to interpret but, since all polyenes tested induce loss of $\mathrm{K}^{+}$from sensitive organisms (Lampen, I966; Zygmunt, I966), it seemed that estimation of this loss with a sensitive $\mathrm{K}^{+}$-responsive electrode would provide a suitable method. A description is given in this paper of the use of such a method to study quantitatively the release of $\mathrm{K}^{+}$from Candida albicans and the conditions affecting that release, to assess the relative action of certain polyenes on Candida and mouse cells, and to study the time course of polyene action on the permeability of Candida membranes together with the effects of sterols on that action. Most of this work has been carried out with the water-soluble amphotericin methyl ester hydrochloride (Mechlinski \& Schaffner, 1972); the structure of amphotericin B has been established by Mechlinski, Schaffner, Ganis \& Avitabile (1970).

\section{METHODS}

Organisms and methods of growth. Three strains of Candida albicans, 6406, 643 I and I8, were clinical isolates obtained from the Mycology Reference Laboratory of the London School of Hygiene and Tropical Medicine. Unless otherwise stated, experiments were carried out with strain 6406. The organisms were cultured on Bacto yeast nitrogen base medium (YNB), $6.7 \mathrm{~g} / 1$ containing $0.5 \%$ glucose; cultures were maintained on agar slopes of the same medium. For routine culture, the organisms were sub-cultured into tubes containing $5 \mathrm{ml} \mathrm{YNB}$-glucose and incubated for $24 \mathrm{~h}$ at $30^{\circ} \mathrm{C}$; these were then used to provide inocula for 21 conical flasks each containing 200 to $250 \mathrm{ml} \mathrm{YNB-glucose.} \mathrm{Flasks}$ were incubated for $18 . \mathrm{h}$ in an orbital incubator at $37^{\circ} \mathrm{C}$, the inoculum size adjusted (usually I to $2 \mathrm{ml}$ per flask) so that organisms were harvested at a suspension density of 0.2 to $0.6 \mathrm{mg}$ dry $\mathrm{wt} / \mathrm{ml}$; exponential growth ceased around a suspension density of $\mathrm{I} \cdot 2$ to $\mathrm{I} \cdot 4 \mathrm{mg} /$ $\mathrm{ml}$ (see Fig. 4, below). Organisms were centrifuged down from the growth medium, washed twice at a density of approx. $5 \mathrm{mg}$ dry wt $/ \mathrm{ml}$ in $0.03 \mathrm{M}$-tris- $\mathrm{HCl}$ buffer $(\mathrm{pH} 7.5)$ and resuspended in that buffer at a density of Io $\mathrm{mg}$ dry wt $/ \mathrm{ml}$. This suspension was then diluted as described below. Densities were determined on a Hilger Absorptiometer (Rank Precision Industries Ltd, Margate, Kent) calibrated against the organisms used.

Mouse fibroblasts, strain LS, were provided by Dr A. A. Newton and were grown in sus- 
pension culture in Eagle's (1959) minimal essential medium (Biocult, Biocult Laboratories Ltd, Paisley, Scotland) supplemented with $5 \%$ tryptose phosphate broth, Ioo units penicillin $/ \mathrm{ml}$, I00 $\mu \mathrm{g}$ streptomycin $/ \mathrm{ml}$, and $5 \%$ ox serum. Cells were harvested from $200 \mathrm{ml}$ while in the exponential phase of growth by centrifuging for $5 \mathrm{~min}$ at $1850 \mathrm{~g}$. They were washed once by resuspension in $10 \%$ sucrose solution, resedimented, and resuspended in I $\%$ sucrose to give a density of about $5 \times 10^{7} \mathrm{cells} / \mathrm{ml}$; I $\mathrm{ml}$ of this suspension was added to I9 $\mathrm{ml} \mathrm{O} \cdot \mathrm{I} \mathrm{M}$-tris- $\mathrm{HCl}$ buffer $\left(\mathrm{pH}_{7} \cdot 5\right)$ with $4 \%$ sucrose as stabilizer, in the electrode vessel.

Materials. Amphotericin B, amphotericin methyl ester hydrochloride, candicidin and perimycin were gifts from Dr C. P. Schaffner, filipin was a gift from Dr G. Whitfield, Upjohn Company, Kalamazoo, Michigan, U.S.A. Nystatin (4800 i.u./mg, $80 \%$ pure), cholesterol and ergosterol were purchased from Sigma Chemical Co., St Louis, Missouri, U.S.A. Certain commercial preparations of amphotericin B, kept dry at $-15{ }^{\circ} \mathrm{C}$, were found to lose all activity over a period of three to four months and have been discarded. Zymosterol was obtained from the Medical Research Council Steroid Reference Collection. Amphotericin methyl ester hydrochloride, nystatin and perimycin were soluble in water at the concentrations required; the other polyenes were dissolved in aqueous alcohol containing the minimum amount of ethanol necessary to effect solution, and controls containing equivalent amounts of ethanol were used with the Candida suspensions. Mouse LS fibroblasts were adversely affected by ethanol and aqueous suspensions of polyenes other than filipin were used in these experiments. Filipin was made up at $10 \mathrm{mg} / \mathrm{ml}$ in ethanol and the small amounts of ethanol then dispensed were tolerated by the cells. Antibiotic solutions were freshly prepared on the day of use.

Inhibition of growth. Candida albicans were inoculated ( $\mathrm{I}^{7}$ to $\mathrm{IO}^{8}$ organisms) into $5 \mathrm{ml}$ quantities of YNB-glucose medium in test-tubes and serial dilutions of drugs added. Growth was inspected after $24 \mathrm{~h}$ at $37^{\circ} \mathrm{C}$ and the minimum inhibitory concentration read by eye.

Estimation of $K^{+}$release. Unless stated otherwise, organisms were suspended at a final density of $\mathrm{I} . \mathrm{O} \mathrm{mg}$ dry $\mathrm{wt} / \mathrm{ml}$ in $20 \mathrm{ml}$ of $0.03 \mathrm{M}$-tris- $\mathrm{HCl}$ buffer $(\mathrm{pH} 7.5)$ at room temperature $\left(20^{\circ} \mathrm{C}\right)$ and stirred by a magnetic flea driven by an air-turbine. Potassium was estimated by the use of a $\mathrm{K}^{+}$-sensitive electrode (type BHI I5, Electronic Instruments Ltd, Richmond, Surrey) connected to measuring unit $\mathrm{C} 33 \mathrm{~B}-2$ and Vibron electrometer 33B-2 (Electronic Instruments Ltd) recording on a potentiometric recorder (Servoscribe RE5II-20, Smith Industries Ltd, Wembley, Middlesex). When not in use, the electrode was kept in O.I M$\mathrm{KCl}$ and the 'bridge' filled afresh each day with $\mathrm{O} \cdot \mathrm{I} \mathrm{M}$-tris- $\mathrm{HCl}$ buffer ( $\mathrm{pH} 7 \cdot 5$ ). The instrument was calibrated against standard solutions of $\mathrm{KCl}$ and could be used effectively to measure $\mathrm{K}^{+}$over the range $3 \times \mathrm{IO}^{-7}$ to $\mathrm{IO}^{-4} \mathrm{M}$. Using the instrument at highest sensitivity, for concentrations of the order of $\mathrm{IO}^{-6} \mathrm{M}-\mathrm{K}^{+}$, a change of $\mathrm{I} n \mathrm{nmol} \mathrm{K}+/ \mathrm{ml}$ corresponded to approx. $4 \mathrm{~cm}$ displacement of the recorder pen. Suspensions of cells prepared as described above gave initial $\mathrm{K}^{+}$concentration readings of $\mathrm{IO}^{-6} \mathrm{M}$ or less; such cells usually showed a small release of $\mathrm{K}^{+}$(although in some cases, especially with organisms freshly harvested early in the exponential phase of growth, uptake of the $\mathrm{K}^{+}$contaminating the suspension took place) and the suspension was left until the recorder showed a constant rate of release. Drug solutions, etc., were then added to the suspension and the record followed as described below.

Protoplasts of Candida albicans 6406 were prepared by Mr M. Marriott by the method of Garcia-Mendoza \& Villanueva (I962) using streptomyces enzyme kindly given by Professor Villanueva. Organisms were harvested in mid-exponential phase and stabilized during enzyme treatment with $0.6 \mathrm{M}-\mathrm{KCl}$. $\mathrm{KCl}$ could not be used for stabilization during 


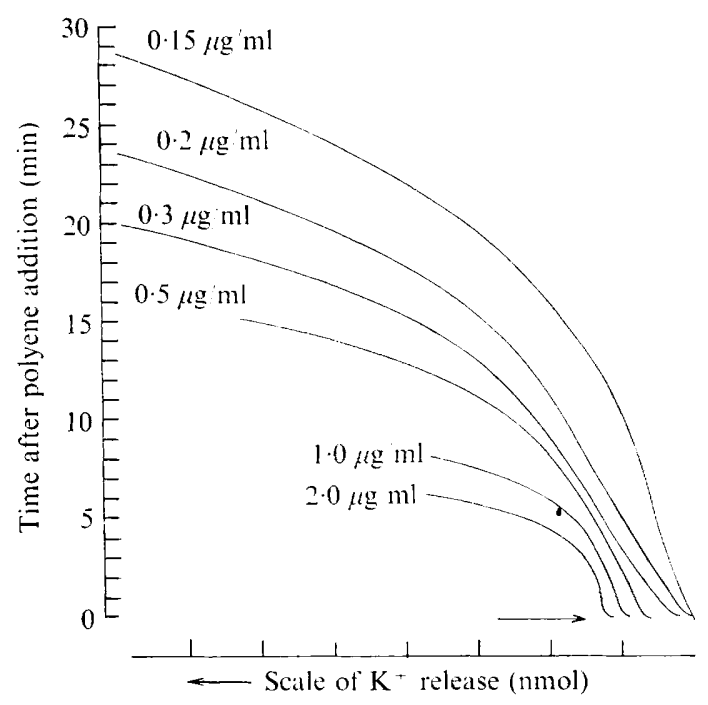

Fig. I. Time course of release of $\mathrm{K}^{+}$from Candida albicans in the presence of amphotericin methyl ester (AME). C. albicans 6406 was harvested in mid-exponential growth, washed twice and suspended at a density of $\mathrm{I} \cdot \mathrm{O} \mathrm{mg}$ dry $\mathrm{wt} / \mathrm{ml}$ in $0.03 \mathrm{M}$-tris-HCl buffer at $\mathrm{pH} 7.5(20 \mathrm{ml})$ in the electrode vessel as described in Methods. Release of $\mathrm{K}^{+}$followed until a steady rate obtained and AME at the final concentrations indicated on the curves was added. The diagram represents the series of traces collected and normalized for the time of AME addition (at arrow). The $\mathrm{K}^{+}$scale is approximate only, as calibration varies to some extent with each curve. The trace was stopped when standard rate of release was obtained in each case.

release tests and it was found satisfactory to wash the protoplasts three times and finally suspend them in $\mathrm{O} \cdot \mathrm{I} \mathrm{M}$-tris- $\mathrm{HCl}$ buffer $\left(\mathrm{pH}_{7} .5\right)$ containing $0.8 \mathrm{M}$-sorbitol as stabilizing agent; the protoplast suspension was made at a density corresponding to $\mathrm{I} \cdot \mathrm{O} \mathrm{mg}$ dry $\mathrm{wt}$ of initial cells/ml.

\section{RESULTS}

\section{Release of potassium in the presence of amphotericin methyl ester (AME)}

Time course and AME concentration. Fig. I reproduces a collection of recorder tracings obtained when AME at varying concentrations was added to a suspension of Candida albicans 6406 . After addition of antibiotic, there was a period before the rate of $\mathrm{K}^{+}$release increased and this lag period depended upon the AME concentration. The rate then increased progressively to values of 20 to $30 \mathrm{nmol} \mathrm{K}^{+} / \mathrm{min} / \mathrm{mg}$ cells until (although this is not shown in Fig. I) the $\mathrm{K}^{+}$content of the cells had equilibrated with that in the medium. In order to use the rate of release as a means of studying the action of the drug quantitatively, the following terms were defined. Standard rate of release (SR): release of I $\mathrm{nmol} \mathrm{K}+/ \mathrm{min} /$ mg dry wt of cells above the release in control cells without drug. Standard release time (SRT): the time taken to attain the standard rate of release. Standard release concentration (SRC): the concentration of drug $(\mu \mathrm{g} / \mathrm{ml})$ which gives rise to SR in a given time; times chosen were either 6 or $8 \mathrm{~min}$ and indicated by SRC (6) and SRC (8) respectively.

Table I shows the relation between the time and drug concentration for organisms harvested at different growth densities; the product time $\times$ drug concentration is approximately constant, especially for longer times, for any given culture and can be used as a guide in the determination of SRC. SRT can be used conveniently to study changes in 
Table I. Relationship between AME concentration and SRT for leakage of $\mathrm{K}^{+}$from Candida albicans

Candida albicans 6406 was suspended at $\mathrm{I} \cdot 0 \mathrm{mg}$ dry wt $/ \mathrm{ml}$ in $0.03 \mathrm{M}$-tris-

Culture

density at

harvesting

( $\mathrm{mg} / \mathrm{ml})$

0.46

$\mathrm{HCl}$ buffer at $\mathrm{pH} 7 \cdot 5$.

$\begin{array}{cc}0.46 & 2.0 \\ & \mathrm{I} \cdot 0 \\ & 0.5 \\ & 0.3 \\ & 0.2 \\ & 0.15 \\ & 0 . \mathrm{I} \\ 0.98 & 4.5 \\ & 2.0 \\ & \mathrm{I} \cdot 5 \\ & \text { Nystatin concn } \\ 0.98 & (\mu \mathrm{g} / \mathrm{ml}) \\ & 5.0\end{array}$

$\begin{array}{cc}\begin{array}{c}\text { AME concn } \\ (\mu \mathrm{g} / \mathrm{ml})\end{array} & \begin{array}{c}\text { SRT } \\ (\mathrm{min})\end{array} \\ 2 \cdot 0 & 5 \cdot 2 \\ \mathrm{I} \cdot 0 & 8 \\ 0 \cdot 5 & 14 \cdot 6 \\ 0 \cdot 3 & 19 \\ 0 \cdot 2 & 24 \\ 0 \cdot 15 & 31 \cdot 5 \\ 0 \cdot \mathrm{I} & 46 \\ 4 \cdot 5 & 14 \\ 2 \cdot 0 & 27 \\ \mathrm{I} \cdot 5 & 38\end{array}$

SRT

$5 \cdot 2$

$14 \cdot 6$

19.8

$24 \quad 4 \cdot 8$

$31 \cdot 5 \quad 4.7$

$46 \quad 4 \cdot 6$

$14 \quad 62$

38

54
58

Nystatin concn

$\times$ SRT

22

IIO

$\mathrm{SRT}$, time required for rate of $\mathrm{K}^{+}$release to attain $\mathrm{I} \mathrm{nmol} / \mathrm{min} / \mathrm{mg}$ over that in control without drug; AME, amphotericin methyl ester.

Table 2. Effect of suspension density and amphotericin methyl ester (AME) concentration on rate of $K^{+}$release from Candida albicans

C. albicans was suspended at the densities shown below in $0.03 \mathrm{M}$-tris- $\mathrm{HCl}$ buffer $\mathrm{pH} 7.5$; AME at the concentrations shown below was added and release followed until the rate was greater than $3.0 \mathrm{nmol} \mathrm{K+} / \mathrm{min}$. Times taken to reach rates of release of $0.3, \mathrm{I} \cdot 0$ and $3.0 \mathrm{nmol} \mathrm{K}^{+} / \mathrm{min}$ were determined.

\begin{tabular}{|c|c|c|c|c|c|c|c|}
\hline Dry weight cells $(\mathrm{mg} / \mathrm{ml})$ & $\cdots$ & $\cdots$ & 0.3 & 0.3 & $\mathrm{I} \cdot \mathrm{O}$ & $3 \cdot 0$ & $3 \cdot 0$ \\
\hline $\operatorname{AME}(\mu \mathrm{g} / \mathrm{ml}) \ldots$ & ... & ... & 0.3 & $I \cdot O$ & $I \cdot 0$ & $1 \cdot 0$ & $3 \cdot 0$ \\
\hline $\begin{array}{c}\mathrm{K}^{+} \text {release rate } \\
(\mathrm{nmol} / \mathrm{min} / \mathrm{ml})\end{array}$ & & & \multicolumn{5}{|c|}{ Time (min) } \\
\hline 0.3 & & & $11 \cdot 7$ & $5 \cdot 8$ & $9 \cdot \mathbf{I}$ & $10 \cdot 6$ & $5 \cdot 1$ \\
\hline $1 \cdot 0$ & & & I $6 \cdot I$ & $8 \cdot I$ & I1 0 & $13 \cdot 5$ & $7 \cdot 3$ \\
\hline $3 \cdot 0$ & & & 23.5 & II $\cdot 5$ & $14 \cdot 8$ & $17 \cdot 8$ & $9 \cdot 1$ \\
\hline \multicolumn{8}{|l|}{$\begin{array}{c}\mathrm{K}^{+} \text {release rate } \\
(\mathrm{nmol} / \mathrm{min} / \mathrm{mg} \text { organisms })\end{array}$} \\
\hline 0.3 & & & 9.5 & 3.5 & $9^{\prime I}$ & $13 \cdot 2$ & $6 \cdot 9$ \\
\hline$I \cdot O$ & & & $11 \cdot 6$ & $5 \cdot 9$ & I I & $17 \cdot 9$ & $9 \cdot 2$ \\
\hline $3 \cdot 0$ & & & $15 \cdot 7$ & $7 \cdot 9$ & I $4 \cdot 8$ & - & \\
\hline
\end{tabular}

response of the order of 2 to 3 times but larger variations are studied by estimation of SRC.

Effect of suspension density. Table 2 shows that the rate of $\mathrm{K}^{+}$release depends upon both drug concentration and suspension density. Decreasing or increasing the suspension density threefold decreases or raises respectively the time taken to reach a given rate of release ( $\mathrm{I} \cdot \mathrm{O}$ or $3.0 \mathrm{nmol} / \mathrm{min} / \mathrm{ml}$ ) by 20 to $25 \%$. If the release is calculated on the basis of nmol $\mathrm{K}^{+} / \mathrm{min} / \mathrm{mg}$ dry wt of organisms, it can be seen that the same rate of release is obtained if the ratio of suspension density to drug concentration remains the same. In a similar experiment in which the drug concentration required to produce a release of I $\mathrm{nmol} \mathrm{K}+/ \mathrm{min} / \mathrm{ml}$ was determined in the presence of suspension densities of $0.3, \mathrm{I} \cdot 0$ and $3.0 \mathrm{mg}$ dry $\mathrm{wt} / \mathrm{ml}$, 


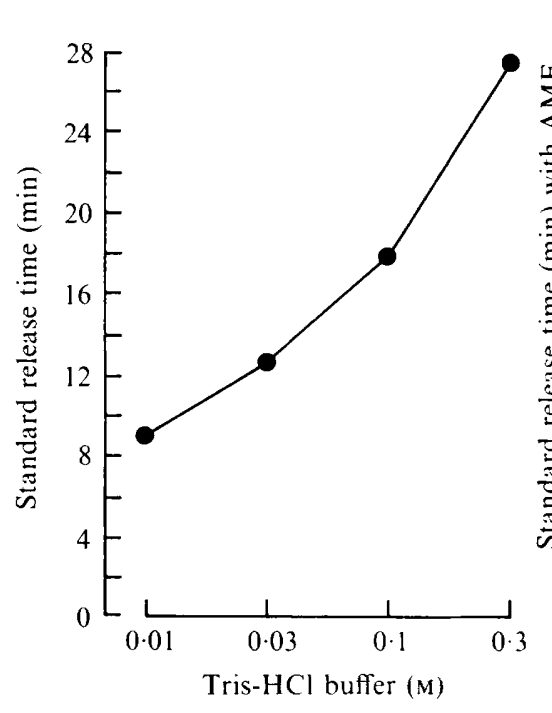

Fig. 2

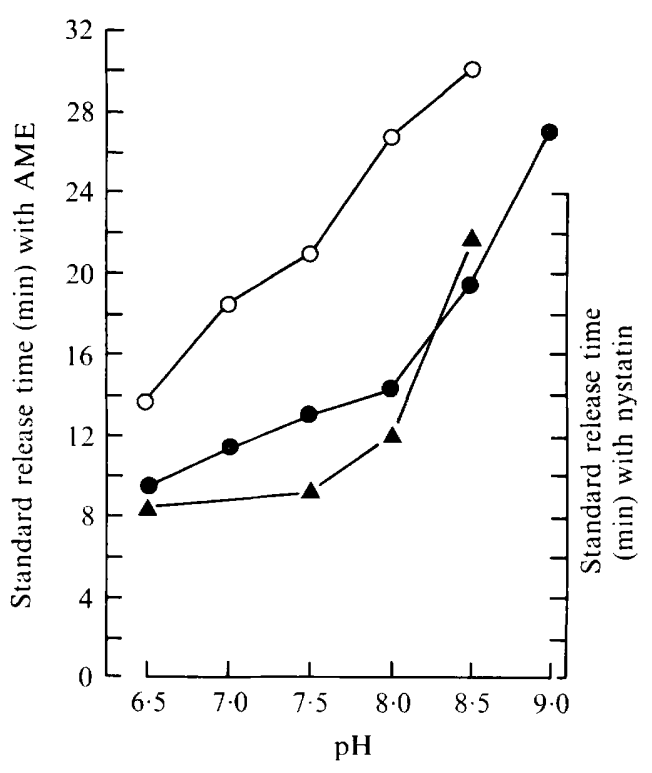

Fig. 3

Fig. 2. Effect of concentration of tris- $\mathrm{HCl}$ buffer on the rate of $\mathrm{K}^{+}$release. Conditions were as for Fig. I except for the concentration of the buffer; $0.25 \mu \mathrm{g}$ AME was added $/ \mathrm{ml}$ and SRT determined (i.e. time taken to give a release of $\mathrm{I} \mathrm{nmol} \mathrm{K}+/ \mathrm{min} / \mathrm{mg}$ organisms in excess of that in the control without drug).

Fig. 3. Effect of $\mathrm{pH}$ on the rate of release of $\mathrm{K}^{+}$from Candida albicans in the presence of AME (in the presence and absence of $\mathbf{I} \cdot 6 \mathrm{nmol}$ ergosterol) and nystatin. Organisms were suspended in $0.03 \mathrm{M}$-tris buffer at the $\mathrm{pH}$ values indicated. (0), $0.4 \mu \mathrm{g} \mathrm{AME} / \mathrm{ml}$ added at time $0 ;(0), 0.4 \mu \mathrm{g}$ $\mathrm{AME}+\mathrm{I} \cdot 6 \mathrm{nmol}$ ergosterol $/ \mathrm{ml}$ added at time $0 ;(\Delta), \mathrm{I} \cdot 0 \mu \mathrm{g}$ nystatin $/ \mathrm{ml}$ added at time 0 .

the values obtained were $0.65, \mathrm{I} \cdot 0$ and $\mathrm{I} \cdot 45 \mu \mathrm{g} \mathrm{AME} / \mathrm{ml}$ respectively. In all other experiments, the suspension density has been standardized at $\mathrm{r} \cdot 0 \mathrm{mg}$ dry $\mathrm{wt} / \mathrm{ml}$.

Effect of $p H$ and strength of buffer. Fig. 2 shows that the time taken to induce the SR increases with the strength of tris- $\mathrm{HCl}$ buffer at $\mathrm{pH} 7 \cdot 5$, while Fig. 3 shows that, both for AME and nystatin, the SRT increases slowly over the $\mathrm{pH}$ range to 8.0 but more rapidly at more alkaline values; the increase at values greater than $\mathrm{pH} 8.0$ is greater for nystatin than for AME. In other experiments quoted, release was studied in $0.03 \mathrm{M}$-tris- $\mathrm{HCl}$ buffer at $\mathrm{pH} 7 \cdot 5$.

Effect of 'age of culture'. Fig. 4 shows the variation of SRC for AME with the time of incubation of Candida albicans I 8 culture. The sensitivity decreases progressively throughout the growth, the rate of decrease being much greater once the culture has entered the stationary phase. Similar variations are obtained with $C$. albicans 6406 , where the SRC is around 0.2 to $0.5 \mu \mathrm{g} \mathrm{AME} / \mathrm{ml}$ for organisms harvested in the early exponential phase but may rise to $10 \mu \mathrm{g} / \mathrm{ml}$ for organisms harvested in the stationary phase of growth. For routine work, organisms were harvested at a culture density of 0.2 to $0.6 \mathrm{mg}$ dry wt $/ \mathrm{ml}$.

Effect of temperature. Lampen et al. (1962) found that the uptake of nystatin by Saccharomyces cerevisiae was temperature dependent. Table 3 shows that the rate of release of $\mathrm{K}^{+}$ from Candida albicans in the presence of AME is also markedly affected by temperature, a change of $10{ }^{\circ} \mathrm{C}$ over the range Io to $30^{\circ} \mathrm{C}$ altering the value of SRT by six to seven times. No release, over that without drug, could be observed at $0^{\circ} \mathrm{C}$ up to $60 \mathrm{~min}$. 

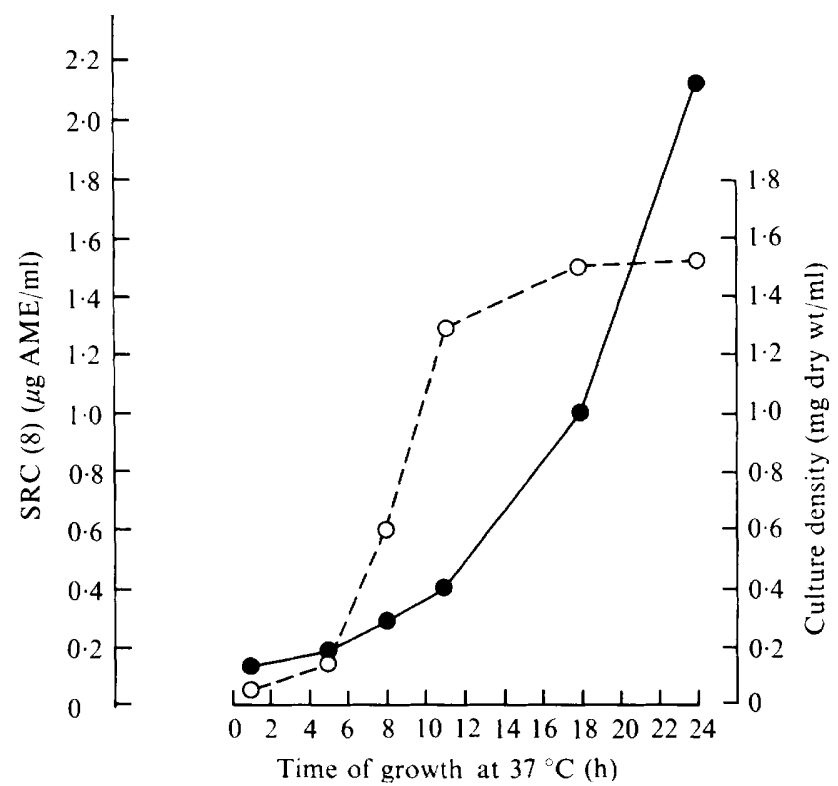

Fig. 4. Effect of 'age of culture' on sensitivity of Candida albicans 18 suspensions to AME. $C$. albicans was grown on a rotary shaker at $37{ }^{\circ} \mathrm{C}$ as described in Methods except that the glucose concentration in the medium was reduced to $0.1 \%$ to limit growth within the experimental period. Organisms were harvested at intervals as shown, washed twice and suspended at $\mathrm{I} \cdot 0 \mathrm{mg} \mathrm{dry} \mathrm{wt} / \mathrm{ml}$ in $0.03 \mathrm{M}$-tris- $\mathrm{HCl}$ buffer ( $\mathrm{pH} \mathrm{7.5)}$. The standard release concentration [SRC(8)] was determined for each culture (i.e. that concentration of AME, in $\mu \mathrm{g} / \mathrm{ml}$, inducing a release of $\mathrm{I} \mathrm{nmol} \mathrm{K}+/ \mathrm{min} / \mathrm{mg}$ organisms, over that in the control without drug, in $8 \mathrm{~min}$ at $\left.20^{\circ} \mathrm{C}\right) .-\mathrm{SRC}(8) ; \mathrm{O}_{---O}$, culture density (mg dry wt $/ \mathrm{ml}$ ) at time of harvest.

Table 3. Effect of temperature on release of $K^{+}$from Candida albicans in the presence of $A M E$

C. albicans was suspended at $\mathrm{I} \cdot 0 \mathrm{mg}$ dry $\mathrm{wt} / \mathrm{ml}$ in $0.03 \mathrm{M}$-tris- $\mathrm{HCl}$ buffer $(\mathrm{pH} 7.5)$ in electrode vessels maintained at temperatures as below. AME was added and SRT determined.

$\begin{array}{ccc}\begin{array}{c}\text { AME } \\ (\mu \mathrm{g} / \mathrm{ml})\end{array} & \begin{array}{c}\text { Temperature } \\ \left({ }^{\circ} \mathrm{C}\right)\end{array} & \begin{array}{c}\text { SRT } \\ (\mathrm{min})\end{array} \\ 1.0 & 20 & 8 \\ & 15 & 30 \\ & 10 & 65 \\ & 0 & \text { No release at } 60 \\ 0.3 & 30 & 20 \\ & 20 & 3.5\end{array}$

For abbreviations, see Table I.

Effect of metabolic inhibitors. The marked effect of temperature on the rate of release of $\mathrm{K}^{+}$might be explained by a requirement for metabolic energy for either the uptake of the antibiotic or the subsequent membrane disorganization process. Table 4 shows that inhibitors such as iodoacetamide and dinitrophenol increase the time required for standard release in the presence of a given concentration of drug. It was not possible to extend the studies to sodium azide, arsenate or cyanide as the electrode was not efficient in the presence of these inhibitors at the concentrations required to affect metabolism. Lampen et al. 
Table 4. Action of metabolic inhibitors

Candida albicans was suspended at $\mathrm{r} \cdot 0 \mathrm{mg}$ dry $\mathrm{wt} / \mathrm{ml}$ in $0.03 \mathrm{M}$-tris- $\mathrm{HCl}$ buffer $(\mathrm{pH} 7.5)$; standard release time after addition of $1.0 \mu \mathrm{g} \mathrm{AME} / \mathrm{ml}$ was determined in the absence and presence of inhibitors as below.

\begin{tabular}{lcc}
\multicolumn{1}{c}{ Inhibitor } & $\begin{array}{c}\text { Concentration } \\
(\mathrm{mM})\end{array}$ & $\begin{array}{c}\text { Standard release time } \\
(\mathrm{min})\end{array}$ \\
None & - & $6 \cdot 5$ \\
Iodoacetamide & 3 & 8 \\
& I0 & 15 \\
Na azide & 30 & $27 \cdot 5$ \\
2,4-Dinitrophenol & I & 7 \\
& I & 9 \\
& 3 & 12
\end{tabular}

Table 5. Sensitivity of Candida albicans cells and protoplasts to amphotericin methyl ester $(A M E)$

C. albicans 6406 was harvested in early exponential growth $(0.05$ to $0.1 \mathrm{mg} / \mathrm{ml}$ culture medium) and suspended at a density of $\mathrm{I} \cdot 0 \mathrm{mg}$ dry $\mathrm{wt} / \mathrm{ml}$ in $0 \cdot \mathrm{I} \mathrm{M}$-tris- $\mathrm{HCl}$ buffer $(\mathrm{pH} 7.5)$ with additions as below; protoplasts were produced by strepzyme treatment and suspended at a density corresponding to $1.0 \mathrm{mg}$ initial cells $/ \mathrm{ml}$, with $0.8 \mathrm{M}$-sorbitol as stabilizer. AME was added and standard release concn $(\mu \mathrm{g} / \mathrm{ml})$ determined for $8 \mathrm{~min}$ release [SRC (8)].

Treatment of cells

(I) Suspended in $\mathrm{O} \cdot \mathrm{I} \mathrm{M}$-tris- $\mathrm{HCl}$

(2) As (I) + $0.8 \mathrm{M}$-sorbitol

(3) Protoplasts formed and suspended in $0.1 \mathrm{M}$-tris- $\mathrm{HCl}+0.8 \mathrm{M}$ sorbitol

(4) Cells treated as (3) less protoplasting enzyme; suspended in $\mathrm{O} \cdot \mathrm{I} \mathrm{M}$-tris- $\mathrm{HCl}$ +0.8 M-sorbitol

\begin{tabular}{|c|c|}
\hline \multicolumn{2}{|c|}{ SRC (8) } \\
\hline Expt I & Expt 2 \\
\hline 0.10 & 0.15 \\
\hline & 0.45 \\
\hline 0.85 & 0.6 \\
\hline & 0.8 \\
\hline
\end{tabular}

(I962) noted that digitonin, which reacts with sterols, extracted nystatin from yeast membranes; Io $\mu \mathrm{M}$-digitonin doubled the SRT when added directly to the organisms at the same time as AME; when the organisms were treated with $10 \mu \mathrm{M}$-digitonin for $4 \mathrm{~h}$ at $20^{\circ} \mathrm{C}$ before the addition of AME they were then resistant to AME (SRC $>20 \mu \mathrm{g} / \mathrm{ml}$ ).

Sensitivity of protoplasts and resistant strain of Candida albicans. The minimum growth inhibitory concentrations of AME for the three strains of Candida albicans, 6406, 18 and $643 \mathrm{I}$, were determined by the conventional growth method using serial dilutions of the drug and inocula of approx. $10^{7}$ to $10^{8}$ organisms $/ \mathrm{ml}$; values of $0.4 \mu \mathrm{g} / \mathrm{ml}$ were obtained for strains 6406 and $\mathrm{I} 8$, and $\mathrm{I} \cdot 2 \mu \mathrm{g} / \mathrm{ml}$ for $643 \mathrm{I}$. The SRC was then determined for $\mathrm{K}^{+}$ release from suspensions of early-exponential phase of the three cultures; values obtained were $0.3,0.7$ and $9.5 \mu \mathrm{g} \mathrm{AME} / \mathrm{ml}$ for strains 6406 , 18 and $643 \mathrm{I}$, respectively.

Table 5 shows the sensitivity of protoplasts of strain 6406 . Protoplasts were first made by the strepzyme method (Garcia-Mendoza \& Villanueva, I962) and showed a marked increase in resistance compared with the parent cell suspension (Table 5, Expt I); however, when organisms were taken through the treatment involved in the protoplast formation, omitting the enzyme, and suspended in tris- $\mathrm{HCl}$ buffer containing $\mathrm{I} \cdot 2 \mathrm{M}$-sorbitol as stabilizer, it was found that there were no significant differences in the sensitivities of protoplasts and the organisms from which they were formed (Table 5, Expt 2).

Sensitivity of Candida albicans and mouse LS cells. Table 6 shows the relative sensitivity 
Table 6. Sensitivity of Candida albicans and mouse LS cells to polyene antibiotics

Cells suspended at $\mathrm{I} \cdot 0 \mathrm{mg} \mathrm{dry} \mathrm{wt} / \mathrm{ml}$ in $0 . \mathrm{I}$ M-tris- $\mathrm{HCl}$ buffer $(\mathrm{pH} 7.5)$ with, for mouse LS cell suspensions, $4 \%(\mathrm{w} / \mathrm{v})$ sucrose added. Standard release concentration [SRC (8)] determined for antibiotics as below.

\begin{tabular}{|c|c|c|c|c|c|c|c|}
\hline \multirow[b]{3}{*}{ Polyene } & \multicolumn{6}{|c|}{ Standard release concentration $(8 \mathrm{~min})(\mu \mathrm{g}$ polyene $/ \mathrm{ml})$} & \multirow{3}{*}{$\underset{b / a}{\text { Ratio }}$} \\
\hline & \multicolumn{3}{|c|}{ Candida albicans 6406} & \multicolumn{3}{|c|}{ Mouse LS cells } & \\
\hline & Range & No. * & Mean $(a)$ & Range & No.* & Mean $(b)$ & \\
\hline $\begin{array}{l}\text { Amphotericin } \\
\text { methyl esther } \\
\text { (AME) }\end{array}$ & $0.45-I \cdot 0$ & 8 & 0.7 & I $2 \cdot 5-18$ & 5 & $15 \cdot 6$ & 22 \\
\hline Nystatin & $1.5-5 \cdot 0$ & 5 & $3 \cdot 3$ & $28-35$ & 3 & 30 & 9 \\
\hline Candicidin & $0.55-I \cdot I$ & 3 & 0.9 & $I \cdot 2-2-3$ & 3 & $I \cdot 7$ & 2 \\
\hline Perimycin & $\mathrm{I} \cdot 5$ & I & & $2 \cdot 0$ & I & & $I \cdot 3$ \\
\hline Filipin & $10-12$ & 5 & I I & $2-3$ & 3 & $2 \cdot 5$ & 0.23 \\
\hline Amphotericin B & $I \cdot 8-5 \cdot 0$ & 5 & $3 \cdot 0$ & $>45$ & I & & $>13$ \\
\hline
\end{tabular}

* Number of different suspensions used for determination of mean value.

to a range of polyene antibiotics of Candida albicans suspension harvested in mid-exponential growth and mouse LS fibroblast cells. In both cases the sensitivity is affected by the stage of growth of the cells and attempts have been made to standardize the conditions as far as possible. Detailed investigations have not been carried out with the fibroblast suspensions and batches have varied in stability; in two instances the suspensions were stable in $\mathrm{O}^{\mathrm{I}} \mathrm{M}$-tris- $\mathrm{HCl}$ buffer containing $0.5 \%$ sucrose, but other batches required $4 \%$ sucrose to prevent rapid $\mathrm{K}^{+}$release in the absence of drug. AME was included as one of the antibiotics in all experiments. Results with amphotericin B have proved variable, probably due to the insolubility of the preparation. The ratio of SRC for yeast and fibroblast cells gives a guide to the selectivity of the drug for the systems used; clear-cut differences in sensitivity have been consistently found for amphotericin methyl ester and nystatin, whereas the two cell types have similar sensitivities for perimycin and candicidin while the mouse LS cells were markedly more sensitive to filipin than C. albicans.

\section{Effect of sterols on $K^{+}$release from Candida albicans in the presence of AME or nystatin}

Effect of sterols added at the same time as the polyene. Preliminary work showed that the addition of cholesterol or ergosterol at the same time as AME reduced the rate of the induced release of $\mathrm{K}^{+}$but the degree of reduction varied widely from experiment to experiment. To carry out these tests, AME was made up in mM solution in water and then diluted to $10^{-4} \mathrm{M}$ in the presence of sterol and samples of the AME/sterol mixture used for the determination of SRT. The sterol solutions contained ethanol and the alcohol content was adjusted to the same value in all mixtures including the AME control. Fig. 3 shows that the $\mathrm{pH}$ of the sterol/AME mixture affects the degree of antagonism subsequently obtained; the results quoted in Table 7 were obtained with sterol/AME mixtures and organisms at $\mathrm{pH} 8.0$ in $0.03 \mathrm{M}$-tris- $\mathrm{HCl}$ buffer. Table 7 shows that the SRT for a given AME concentration is increased by a variety of sterols; the most effective polyene antagonist of the sterols tested was zymosterol (5 experiments). Ergosterol was approximately twice as effective as cholesterol at the same sterol/AME ratio. It can be seen from Table 7 that ergosterol had some antagonism towards nystatin whereas cholesterol had no significant action under the conditions used. 


\section{Table 7. Effect of sterols on the release of $\mathrm{K}^{+}$from Candida albicans in the presence of polyenes}

C. albicans at a density of $\mathrm{I} \cdot 0 \mathrm{mg}$ dry $\mathrm{wt} / \mathrm{ml}$ was suspended in $0.03 \mathrm{M}$-tris- $\mathrm{HCl}$ buffer $(\mathrm{pH} 8.0$ ). Drug solutions were made up in $0.03 \mathrm{M}$-tris- $\mathrm{HCl}$ buffer $\left(\mathrm{pH} 8.0\right.$ ) containing $10^{-4} \mathrm{M}-\mathrm{AME}$ (mol. wt. 972 ) or $2 \times 10^{-4} \mathrm{M}$-nystatin (mol. wt 929), sterol as below, and $10 \%(\mathrm{v} / \mathrm{v}$ ) ethanol; samples were taken and added to the electrode vessel $(20 \mathrm{ml}$ mixture) to give final drug concentrations as below.

\begin{tabular}{|c|c|c|c|c|c|c|}
\hline $\operatorname{AME}\left(\mu_{\mathrm{M}}\right)$ & $\cdots$ & 0.8 & $I \cdot 4$ & $I \cdot 6$ & 0.5 & 一 \\
\hline Nystatin $\left(\mu_{\mathrm{M}}\right)$ & $\ldots$ & 一 & 一 & - & 一 & 3 \\
\hline & Molar ratio: & & Stan & release $t$ & $\min )$ & \\
\hline Sterol & $\overrightarrow{\text { Polyene }}$ & Expt I & Expt 2 & Expt 3 & Expt 4 & Expt 5 \\
\hline None & o & $10 \cdot 3$ & $7 \cdot 5$ & $6 \cdot 5$ & $12 \cdot 0$ & $16 \cdot 5$ \\
\hline Cholestane & 3 & 一 & - & IO I I & 一 & 一 \\
\hline $\begin{array}{l}\text { I,4-Pregnadiene- } \\
\text { I I } \beta, \text { I 7,2 I-triol- } \\
\text { 3,20-dione }\end{array}$ & 3 & - & - & $10 \cdot 8$ & 一 & 一 \\
\hline Cholesterol & 2 & $13 \cdot 2$ & $10 \cdot 0$ & - & 一 & 一 \\
\hline & 3 & - & - & I $3 \cdot 0$ & - & - \\
\hline & 4 & $15 \cdot 6$ & $15 \cdot 5$ & - & 16 & - \\
\hline & 6 & $18 \cdot 5$ & - & - & - & $17 \cdot 0$ \\
\hline Stigmasterol & 3 & - & - & $14 \cdot 0$ & 一 & 一 \\
\hline Ergosterol & 2 & $14 \cdot 3$ & $13 \cdot 0$ & - & 一 & 一 \\
\hline & 3 & 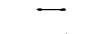 & - & $21 \cdot 0$ & - & - \\
\hline & 4 & $20 \cdot 2$ & $20 \cdot 3$ & - & 20 & $21 \cdot 0$ \\
\hline & 6 & $26 \cdot 4$ & - & - & - & $23 \cdot 0$ \\
\hline Zymosterol & 4 & - & - & - & $3 I$ & - \\
\hline
\end{tabular}

Effect of ergosterol added after removal of $A M E$. Fig. I indicates that damage to the membrane of Candida albicans by AME is progressive and raises two questions: will the rate of $\mathrm{K}^{+}$release continue to increase if the organisms are removed from the drug after a short period of exposure, and can the damage be stopped or reversed by the presence of sterol after removal of the drug? Organisms have been suspended under the usual conditions and the SRC determined for AME; further samples have then been suspended in the presence of the SRC and higher concentrations of AME, shaken for I to $4 \mathrm{~min}$ at room temperature, the organisms centrifuged, the supernatant medium removed as completely as possible and the organisms resuspended at a density of $1.0 \mathrm{mg} / \mathrm{ml}$ in $0.03 \mathrm{M}$-tris- $\mathrm{HCl}$ buffer $(\mathrm{pH} 7.5)$ in the electrode vessel (dilution of drug left in the pellet $>$ Ioo times); readings were taken as soon as the assembly had equilibrated. If organisms were resuspended after initial treatment with drug for 2 min plus the time required for centrifuging, draining and resuspension - a total of $8 \mathrm{~min}$ - readings could be taken from Io min ( 2 min after resuspension) and experiments showed that linear increase in the rate of $\mathrm{K}^{+}$release then occurred. Decreasing the initial period of treatment gave inconsistent results. Fig. 5 shows the rates of release obtained after resuspension of organisms (SRC $=0.7 \mu \mathrm{g} \mathrm{AME} / \mathrm{ml}$ ) after initial exposure to different concentrations of the drug: values for the rates of release in organisms resuspended after the same treatment in the absence of drug have been subtracted in all cases (see Fig. 6a). Organisms resuspended after initial treatment with SRC showed a small release over that of control after some $20 \mathrm{~min}$. Higher initial concentrations of drug gave rise to faster increases in release rate on resuspension and an initial concentration $\mathrm{I} \cdot 5$ to 2 times SRC was adopted for further experiments. It is clear that 


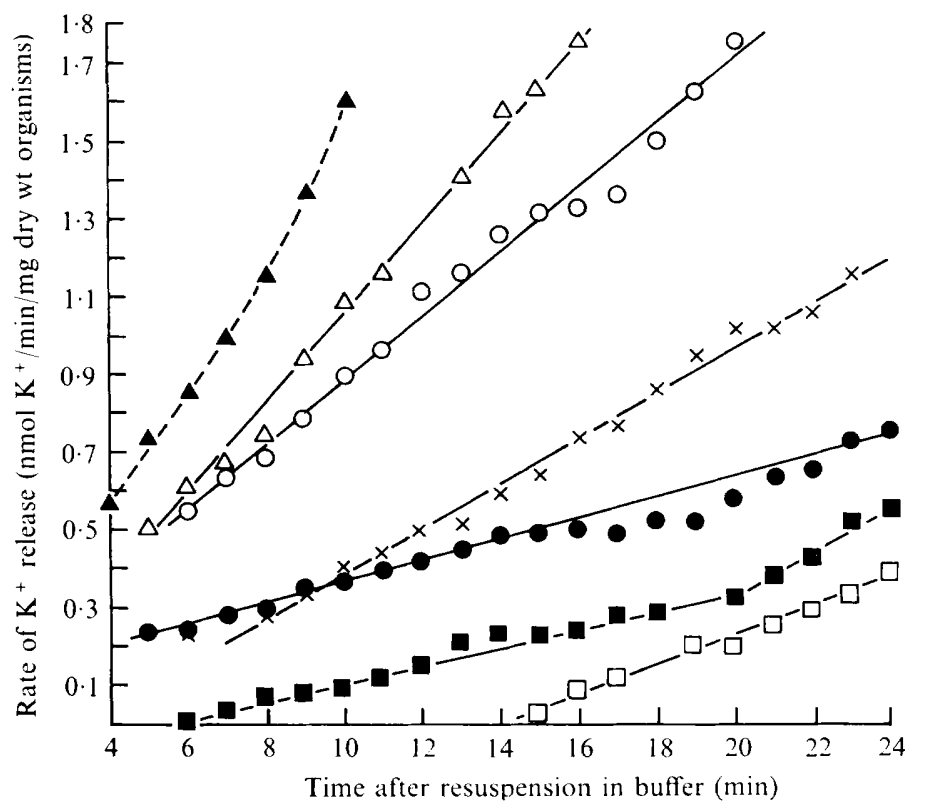

Fig. 5. Rate of $\mathrm{K}^{+}$release from Candida albicans 6406 exposed to AME and resuspended in the absence of drug. C. albicans was suspended at $1.0 \mathrm{mg}$ dry wt $/ \mathrm{ml}$ in $0.03 \mathrm{M}$-tris-HCl buffer $(\mathrm{pH} 7.5$ ) containing AME as below; after $2 \mathrm{~min}$ at $20^{\circ} \mathrm{C}$, organisms were centrifuged, the supernatant was removed quantitatively and the pellet resuspended at $\mathrm{I} .0 \mathrm{mg}$ dry $\mathrm{wt} / \mathrm{ml}$ in $0.03 \mathrm{M}$-tris- $\mathrm{HCl}$ buffer $(\mathrm{pH} 7.5) ; \mathrm{K}^{+}$release was studied over the next $30 \mathrm{~min}$. The concentrations of AME present during the initial period of $8 \mathrm{~min}$ were as follows $(\mu \mathrm{g} / \mathrm{ml}):(\square), 0 \cdot 7 ;(\square), 0 \cdot 8 ;(0), \mathrm{I} \cdot 0 ;(\times), \mathrm{I} \cdot 25 ;(0), \mathrm{I} \cdot 35 ;$ $(\triangle), I \cdot 50$. (A), Initial AME concentration $0.7 \mu \mathrm{g} / \mathrm{ml}$; cells resuspended in buffer containing $0.7 \mu \mathrm{g} \mathrm{AME} / \mathrm{ml}$.

damage initiated during the $8 \mathrm{~min}$ exposure to AME progresses after removal of the drug from the medium.

The effect of the presence of ergosterol in the medium after resuspension was then tested. Fig. 6(a) shows the release obtained after resuspension of organisms, pretreated in the presence or absence of AME, in buffer alone or with the addition of $2 \times 10^{-5} \mathrm{M}$ ergosterol. The addition of ergosterol to resuspended control organisms results in a transient increase in the rate of $\mathrm{K}^{+}$release and Fig. $6(b)$ shows that, when the appropriate controls are taken into account, $2 \times \mathrm{IO}^{-5} \mathrm{M}$-ergosterol largely prevents the increase in release that takes place in drug-treated organisms. Table 8 shows the effect of ergosterol concentration; under the conditions used in these experiments $2 \times 1 \mathrm{O}^{-5} \mathrm{M}$-ergosterol gave the greatest protection against further damage initiated by approx. $\mathrm{IO}^{-6} \mathrm{M}-\mathrm{AME}$. Smaller or higher concentrations of ergosterol were less effective and it has not been possible to demonstrate any reversal of AME damage in the sense of a decreased rate of release after resuspension in the presence of ergosterol. An interesting finding is that at high concentrations $\left(\mathrm{IO}^{-4} \mathrm{M}\right)$ ergosterol increased the rate of release in AME-treated organisms but had no progressive effect on control organisms. 

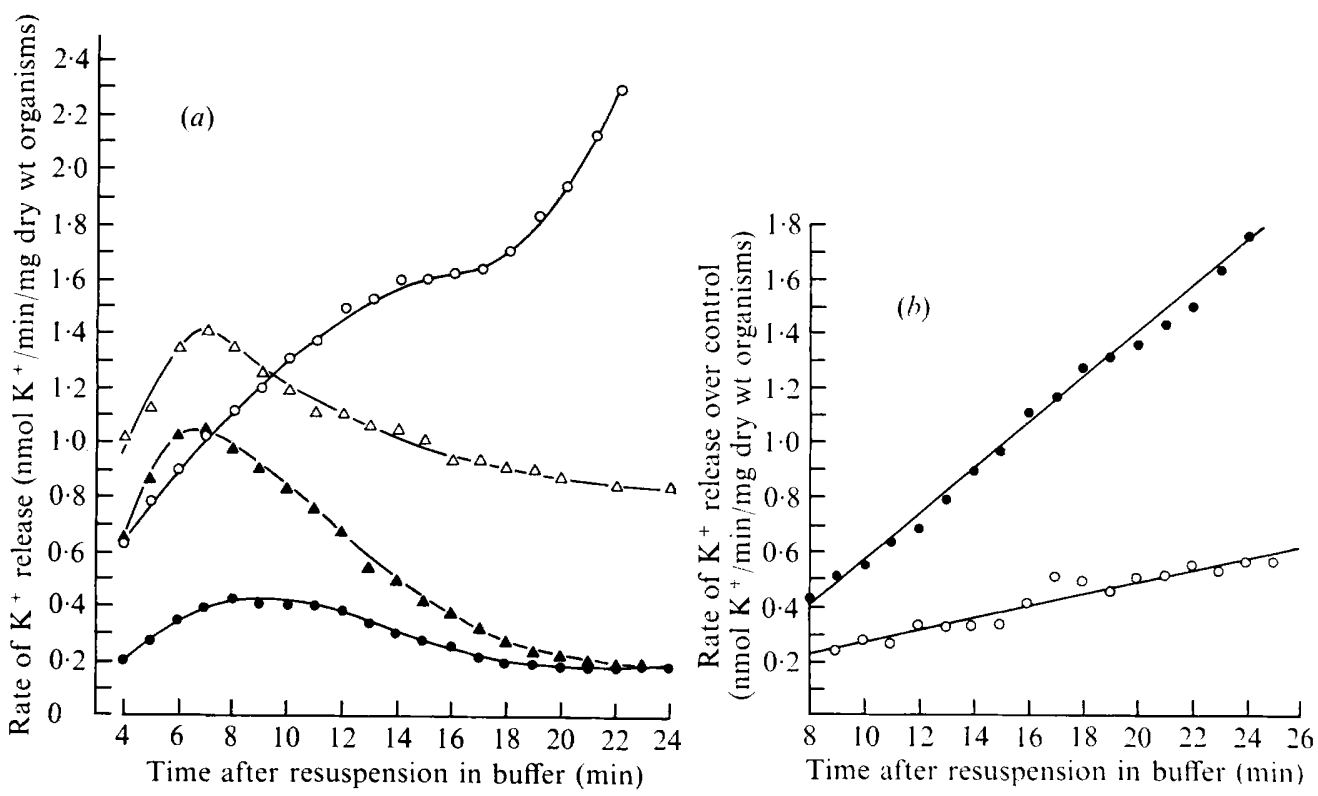

Fig. 6. Effect of ergosterol on the release of $\mathbf{K}^{+}$from Candida albicans 6406 exposed to AME and then resuspended in buffer without drug. (a) Conditions were as for Fig. 5. Organisms were initially suspended in $0.03 \mathrm{M}$-tris- $\mathrm{HCl}$ buffer $(\mathrm{pH} 7.5)$ with or without $\mathrm{I} \cdot 35 \mu \mathrm{g} \mathrm{AME} / \mathrm{ml}(\mathrm{I} \cdot 39 \mu \mathrm{M})$; they were centrifuged and resuspended as follows: (๑), Initial treatment, no drug; resuspended in buffer. (A), Initial treatment, no drug; resuspended in buffer containing $2 \times 10^{-5} \mathrm{M}$-ergosterol. ( $\triangle$ ), Initial treatment, $\mathrm{I} \cdot 35 \mu \mathrm{g} \mathrm{AME} / \mathrm{ml}$; resuspended in buffer containing $2 \times 10^{-5} \mathrm{M}$-ergosterol. (O), Initial treatment, $\mathrm{r} \cdot 35 \mu \mathrm{g} \mathrm{AME} / \mathrm{ml}$; resuspended in buffer. (b) (O), Release of $\mathrm{K}^{+}$from organisms pretreated with AME and resuspended in the presence of $2 \times 10^{-5} \mathrm{M}$-ergosterol (curve $\triangle$, Fig. $6 a$ ) corrected for control (curve $\Delta$, Fig. $6 a$ ). (), Release of $\mathrm{K}^{+}$from organisms pretreated with AME (curve O, Fig. 6a) corrected for control (curve , Fig. $6 a$ ).

\section{Table 8. Effect of ergosterol on the rate of release of $K^{+}$from Candida albicans after treatment with $A M E$}

Organisms were suspended at $\mathrm{I} \cdot 0 \mathrm{mg}$ dry wt $/ \mathrm{ml}$ in $0.03 \mathrm{M}$-tris- $\mathrm{HCl}$ buffer $(\mathrm{pH} 7.5)$ with or without $\mathrm{I} \cdot 25 \mu \mathrm{g} \mathrm{AME} / \mathrm{ml}$, and shaken at $20^{\circ} \mathrm{C}$ for $2 \mathrm{~min}$; the organisms were centrifuged, the supernatant removed and the organisms resuspended at $\mathrm{I} \cdot 0 \mathrm{mg} / \mathrm{ml}$ in $0.03 \mathrm{M}$-tris- $\mathrm{HCl}$ buffer, $\mathrm{pH} 7.5(8 \mathrm{~min}$ from first suspension); ergosterol was added to give a final concentration as below and readings were started after a further 2 min (see Fig. $6 a$ for nature of time course). Results for AME-treated organisms are corrected for controls without drug treatment.

\begin{tabular}{|c|c|c|c|c|}
\hline \multirow[b]{2}{*}{$\begin{array}{c}\text { Pretreatment } \\
\text { AME } \\
(\mu \mathrm{g} / \mathrm{ml})\end{array}$} & \multirow{2}{*}{$\begin{array}{l}\text { Ergosterol } \\
\text { added after } \\
\text { resuspension } \\
\text { at } 8 \text { min } \\
\text { (M) }\end{array}$} & \multicolumn{3}{|c|}{$\begin{array}{c}\mathrm{K}^{+} \text {release rate } \\
\text { (nmol } / \mathrm{min} / \mathrm{mg} \text { organisms) }\end{array}$} \\
\hline & & $\begin{array}{l}2 \text { min after } \\
\text { resuspension }\end{array}$ & $\begin{array}{l}22 \text { min after } \\
\text { resuspension }\end{array}$ & $\begin{array}{c}\text { Increase } \\
(2 \text { to } 22 \mathrm{~min})\end{array}$ \\
\hline 0 & $\begin{array}{c}0 \\
10^{-5} \\
2 \times 10^{-5} \\
4 \times 10^{-5} \\
\mathrm{IO}^{-4}\end{array}$ & $\begin{array}{l}0.15 \\
0.37 \\
0.45 \\
0.68 \\
0.49\end{array}$ & $\begin{array}{l}0 \cdot 13 \\
0 \cdot 26 \\
0 \cdot 30 \\
0 \cdot 33 \\
0 \cdot 42\end{array}$ & $\begin{array}{c}- \\
- \\
-\end{array}$ \\
\hline $\mathrm{I} \cdot 25(\mathrm{I} \cdot 28 \mu \mathrm{M})$ & $\begin{array}{c}0 \\
10^{-5} \\
2 \times 10^{-5} \\
4 \times 10^{-5} \\
10^{-4}\end{array}$ & $\begin{array}{l}0.32 \\
0.32 \\
0.25 \\
0.24 \\
0.25\end{array}$ & $\begin{array}{l}I \cdot 38 \\
0 \cdot 88 \\
0 \cdot 53 \\
I \cdot 03 \\
I \cdot 67\end{array}$ & $\begin{array}{l}I \cdot 06 \\
0 \cdot 56 \\
0 \cdot 28 \\
0 \cdot 79 \\
I \cdot 42\end{array}$ \\
\hline
\end{tabular}




\section{DISCUSSION}

Exposure of Candida albicans to AME results in progressive damage to the cell membrane as judged by the rate of release of $\mathrm{K}^{+}$from inside the organism. The release takes place at an increasing rate even if the organisms are removed from AME-containing medium and it would appear that changes in membrane organization take place during and after the organisms have taken up the drug. Cass et al. (1970) suggested that micelle formation between polyene and sterol molecules takes place and that the joining of micelles on opposite sides of the membrane can give rise to aqueous pores through that membrane. The steady development of increasing permeability towards $\mathrm{K}^{+}$could be a consequence of the changes in formation and distribution of micelles in the membrane after uptake of the drug. An alternative explanation would be that AME initially binds to non-specific surface structures and then redistribution occurs; the action of ergosterol in preventing further changes of permeability in organisms resuspended in the absence of drug would then be due to removal of AME from non-specific sites before redistribution occurs.

The electrode method described in this paper enables an assessment to be made of the sensitivity of cells of different species and its variation under different conditions. Cells classified as resistant as a result of conventional growth tests require a higher concentration of $\mathrm{AME}$ to produce a given change in $\mathrm{K}^{+}$permeability than do cells classified as sensitive. Mouse LS cells were 10 to 30 times more resistant to amphotericin, AME and nystatin than Candida albicans suspensions; little difference in sensitivity was found for perimycin and candicidin whereas mouse cells proved more sensitive to filipin than the yeast.

Lampen et al. (1962) found that labelled nystatin or $\mathrm{N}$-acetylcandidin was rapidly taken up at $0^{\circ} \mathrm{C}$ by isolated cell walls or protoplast membranes from Saccharomyces cerevisiae, whereas the binding sites were relatively inaccessible or unreactive in intact organisms so that binding was slow at $0^{\circ} \mathrm{C}$. Table 3 confirms the absence of response at $0{ }^{\circ} \mathrm{C}$ for Candida albicans and shows that the release of $\mathrm{K}^{+}$has a high temperature coefficient. The release of $\mathrm{K}^{+}$must be the result of a complex series of events following uptake of the drug, and immobility of the membrane lipid at low temperatures may be a further factor in the absence of response at $0^{\circ} \mathrm{C}$. Lampen et al. (1962) suggested that metabolic energy might be required to alter the accessibility of sites or to move antibiotics to them; Table 4 shows that inhibitors such as iodoacetamide and dinitrophenol markedly increase the time taken for AME to affect the permeability but no metabolic inhibitor has so far been found which completely prevents the effect of AME.

The inhibition of growth produced by polyene antibiotics can be antagonized by addition of sterols to the test medium (Gottlieb et al. 1960; Zygmunt \& Tavormina, I966; Lampen, I966) while sterols reduce the rate of $\mathrm{K}^{+}$release in the presence of AME or nystatin as shown above. However, Table 7 shows that ergosterol added to the suspension at a concentration 4 to 6 times that of AME reduces the action of the latter by not more than 60 to $75 \%$. The complete antagonism reported in growth tests must rest on a number of factors, including delay in the onset of damage in the presence of sterol, rapid inactivation of some polyenes under the conditions of the growth tests, and the action of ergosterol in preventing further damage to the cells after the drug has been removed (Fig. 6). It has not been possible to reverse or repair damage in cells exposed to AME by subsequent addition of ergosterol, and Lampen et al. (1962) reported that labelled nystatin, once bound, could not be displaced by excess cold drug.

Results given here and by others indicate that polyene antibiotics react with sterols and their action can be antagonized by sterols. It is of interest that the immunosuppressive 
drug I,4-pregnadiene-I $\beta, \mathrm{I} 7,2 \mathrm{I}$-triol-3,20-dione reduces the action of AME (Table 7). Of the sterols tested, zymosterol was the most effective in reducing the action of AME, and ergosterol was about twice as active as cholesterol on a molar basis. The interpretation of 'antagonism' data must await further experiments on the absorption of the drug in the presence and absence of sterols but it would seem probable that ergosterol has a higher affinity for AME and nystatin than does cholesterol. Since ergosterol forms the major sterol in Candida albicans membranes (M. Marriott, unpublished) while cholesterol is the main sterol of mammalian cells, such a difference in affinity could provide the basis for the selective effect shown in Table 6 and the reason why AME, amphotericin B and nystatin can be used for the treatment of Candida infections in Man.

I am indebted to Dr C. P. Schaffner and Dr G. Whitfield for generous gifts of antibiotics, to Dr A. A. Newton for supplying suspensions of mouse LS cells and to Mr M. Marriott for providing protoplast suspensions of Candida albicans.

\section{REFERENCES}

ANDreoli, T. E. \& Monahan, M. (1968). The interaction of polyene antibiotics with thin lipid membranes. Journal of General Physiology 52, 300-325.

BitTMAN, R. \& FischkofF, S. A. (1972). Fluorescence studies of the binding of the polyene antibiotics filipin III, amphotericin B, nystatin and lagosin to cholesterol. Proceedings of the National Academy of Sciences of the United States of America 69, 3795-3799.

Borowski, E. \& CYBULSKA, B. (1967). Potassiumless death of Saccharomyces cerevisiae cells treated with $\mathrm{N}$-succinyl perimycin and the reversal of fungicidal action of the antibiotic by potassium ions. Nature, London 213, 1034-1035.

Cass, A., Finkelstein, A. \& Krespi, V. (1970). The ion permeability induced in thin lipid membranes by the polyene antibiotics nystatin and amphotericin B. Journal of General Physiology 56, 100-124.

Eagle, H. (1959). Amino acid metabolism in mammalian cell cultures. Science, New York r30, 432-437.

FinkelsteIn, A. \& CASs, A. (1968). Permeability and electrical properties of thin lipid membranes. Journal of General Physiology 52, 145-173.

Garcia-Mendoza, C. \& Villanueva, J. R. (1962). Production of yeast protoplasts by an enzyme preparation of Streptomyces sp. Nature, London 195, 1326-1327.

Gottlieb, D., Carter, H. E., Wu, L. C. \& Sloneker, J. H. (1960). Inhibition of fungi by filipin and its antagonism by sterols. Phytopathology 5o, 594-603.

Holts, R. \& Finkelstein, A. (1970). The water and non-electrolyte permeability induced in thin lipid membranes by the polyene antibiotics, nystatin and amphotericin B. Journal of General Physiology 56, I25-145.

LAMPEN, J. O. (1966). Interference by polyene antifungal antibiotics (especially nystatin and filipin) with special membrane functions. Symposia of the Society for General Microbiology 16, I I I-I30.

LAMPEN, J. O., ARNOW, P. M., BorowSKA, Z. \& LASKIN, A. I. (1962). Location and role of sterol at nystatinbinding sites. Journal of Bacteriology 84, I $152-1160$.

Lampen, J. O., Gill, J. W., Arnow, P.M. \& Magana-Plaza, L. (1963). Inhibition of the pleuropneumonialike organism Mycoplasma gallisepticum by certain polyene antifungal antibiotics. Journal of Bacteriology 86, 945-949.

MeChlinSKI, W. \& SCHAFFNer, C. P. (1972). Polyene macrolide derivatives. I. $N$-acylation and esterification reactions with amphotericin B. Journal of Antibiotics 25, 256-258.

Mechlinski, W., SchaffNer, C. P., Ganis, P. \& Avitabile, G. (1970). Structure and absolute configuration of the polyene macrolide antibiotic amphotericin B. Tetrahedron Letters 44, 3873-3876.

Norman, A. W., Demel, R. A., de Kruyff, B., Guerts Van Kessel, W. S. H. \& Van Deenen, L. L. M. (1972). Studies on the biological properties of polyene antibiotics: comparison of other antibiotics with filipin in their ability to interact specifically with sterol. Biochimica et biophysica acta 290, I-I4.

SCHAFfNer, C. P. (1973). The biochemical implications of polyene macrolide-sterol interaction. Proceedings of the International Fermentation Symposium (in the Press). 
Verkleij, A. J., de Kruijff, B., Gerritsen, W. G., Demel, R. A., Van Deenen, L. L. M. \& Ververgaert, P. H. J. (1973). Freeze-etch electron microscopy of erythrocytes, Acholeplasma laidlawii cells and liposomal membranes after the action of filipin and amphotericin B. Biochimica et biophysica acta 291, 577-58 I.

Weber, M. M. \& KinsKy, S. C. (1965). Effect of cholesterol on the sensitivity of Mycoplasma laidlawii to the polyene antibiotic filipin. Journal of Bacteriology 89, 306-3 2.

Zygmunt, W. A. (1966). Intracellular loss of potassium in Candida albicans after exposure to polyene antifungal antibiotics. Applied Microbiology 14, 953-956.

Zygmunt, W.A. \& TAvormina, P.A. (1966). Steroid interference with antifungal activity of polyene antibiotics. Applied Microbiology r4, 865-869. 